\title{
En fabel om idrætten i Aalborg
}

\author{
af Jens Topholm
}

,Idræt i Aalborg gennem hundrede år "

Forfatter, Eivind Samuelsen

Udgivet af Samvirkende Idræts-Foreninger i Aalborg (SIFA)

I 1979 nedsatte Samvirkende Idræts-Foreninger i Aalborg (SIFA) et udvalg for at kulegrave udviklingen gennem tiderne inden for Aalborgs idrætsliv. Baggrunden var bl.a. idrættens stærkere placering i vores samlede kulturhistorie. Udvalgets virksomhed har resulteret $i$ en øget indsamling og registrering af materiale til belysning af idrætshistorien i Aalborgområdet. Der er foretaget interviews, indsamlet protokoller, scrapbøger, fotos m.v. I 1981 udgav SIFA bogen „Eugen Schmidt". Idrættens Forkæmper. Hele dette arbejde foregår $\mathrm{i}$ tæt forbindelse med Lokalhistorisk Arkiv for Aalborg kommune.

Bogen „Idræt i Aalborg gennem hundrede år" er et resultat af det historiske udvalgs formidlingsarbejde. Teksten er skrevet af Aalborg Stiftstidendes mangeårige sportsredaktør, Eivind Samuelsen, bistået af en redaktion fra SIFA.

Bogens erklærede formål er at fortælle ,,i fabulerende form om idrætslivet i Aalborgområdet fra 1862 til midt i 1960'erne", og således lægges der ud fra starten: „Det var mørkt, da malersvend Jens Christian Grøndahl vendte hjem til forældrene. Hans far havde tændt petroleumslampen ... Moderen havde strikketøjet fremme". Grøndahl var samme dag blevet fuglekonge, og det var medlemmerne af de nystiftede skyttekredse i Aalborg og Nørresundby, der havde mødtes denne kolde oktoberdag i 1862. Hermed er fortællingen om Aalborgs idrætshistorie i gang.

Vi hører om skytterne og gymnasterne, der var de første til at organisere sig, og om den engelske sports fremmarch - først ved cricket, senere fodbold, atletsport, roning og atletik. De organisatoriske pionerer, bl.a. Eugen Schmidt, får også et par ord med på vejen. I perioden efter 1 . verdenskrig fremhæves nye foreningsdannelser og arbejdet for de første større idrætsanlæg, succesrige olympiadedeltagere og kampe mod professionelle fodboldhold fra England. I 1930'rne står de store arrangementer i 
centrum: den årligt tilbagevendende idrætsuge og Kildeløbet. „Idrætten trivedes trods arbejdsløshedens svøbe " hedder et kapitel, hvor der berettes om en ny tribune på stadion og en ny Aalborghal. Endvidere opstod mange nye foreninger i denne periode inden for f.eks. badminton, svæveflyvning, kvindegymnastik m.m. Forholdene under 2 . verdenskrig beskrives med episoder omkring rationering, forsamlingsforbud, okkupation af idrætsanlæg, fraternisering m.m. Teksten suppleres med erindringsglimt specielt fra besættelsestiden. Tiden efter 1945 behandles $i 6$ afsnit om den olympiske ilds vej gennem Aalborg i 1952, demonstration for tipstjenesten i 1948, boldklubben Chang, cricketdynastiet Morild, Aalborg Boksealliance og endelig om de mange nye idrætsanlæg i 1960'erne.

Herefter følger et afsnit med udpluk af erindringer: „Idrætsveteraner fortæller", og bogen slutter med tekst og billedkavalkade fra Ungdomslegene i Aalborg 1975, 1979 og 1983, samt en oversigt over SIFA's nuværende medlemmer.

Som bekendt må man ikke forvente, at der falder pærer ned, når man står under et æbletræ, og bogen er, hvad den lover: en fabel over idrætslivet $i$ Aalborg gennem 100 år. Den er levende og spændende skrevet og let læst. Der er et væld af enkeltoplysninger om personer, idrætsanlæg og klubber. Illustrationsmaterialet: fotos, kort, annoncer m.v., er righoldigt og understøtter/udvider teksten. Bag den fabulerende form ligger en historisk rygrad: fra skydning over gymnastik til sportens gennembrud og udvikling. Dette gælder dog især bogens første halvdel; jo længere vi kommer op i det 20. årh., jo mere tager fabelen overhånd. Det bliver $\mathrm{i}$ højere grad enkelthistorier og episoder uden sammenhæng med en generel udvikling. Det gælder især for perioden efter 1945. - De mange oplysninger, der ligger i bogen, gør savnet af indholdsfortegnelse og registre ekstra stort, og selv om billedmaterialet er godt oplyst savnes i næsten alle tilfælde fotografen, for nu at være krakilsk. Men angivelse af dette kan f.eks. give et fingerpeg om, hvem der var god til at tage sportsbilleder, og det er vel også rimeligt over for fotografen. En manglende dokumentation ses også ved de mange notitser med uddrag fra erindringer og aviser, der ellers med heldig hånd er spredt rundt $i$ bogen.

Men hvorfor nu begynde at forlange noget, der ikke er lagt op til? Det er et godt initiativ SIFA har taget, og det er en spændende bog Eivind Samuelsen har skrevet. Man kan kun ønske at andre idrætssamvirker på samme måde tager hånd om deres fortid og $\mathrm{i}$ samarbejde med eksisterende lokale kulturinstitutioner indsamler, registrerer og formidler idrætshistorie - det sidste bl.a. på basis af de lokale donatorer, det er nødvendigt at alliere sig med, og som der heldigvis er mange af, selv om de måske ikke ved det endnu. Man kan også kun ønske, at der startes med en lokal appetitvækker og oversigt som denne. Så kan man i næste omgang måske blande 
journalisten med en historiker og vælge et emne eller en periode, som kan undersøges til bunds. Men det er en helt anden historie, og den skal nok komme - bl.a. inspireret af bøger som ,Idræt i Aalborg gennem hundrede år". 